\title{
Article
}

\section{The Acoustics of the Benevento Roman Theatre}

\author{
Silvana Sukaj $^{1}$, Giuseppe Ciaburro ${ }^{2} \mathbb{D}$, Gino Iannace ${ }^{2}\left(\mathbb{D}\right.$, Ilaria Lombardi ${ }^{3}$ and Amelia Trematerra $^{2, *(D)}$ \\ 1 Department of Engineering and Architecture, European University of Tirana (UET), 1023 Tirana, Albania; \\ silvana.sukaj@uet.edu.al \\ 2 Department of Architecture and Industrial Design, Università degli Studi della Campania Luigi Vanivitelli, \\ 81031 Aversa, Italy; giuseppe.ciaburro@unicampania.it (G.C.); gino.iannace@unicampania.it (G.I.) \\ 3 Department of Engineering, Università degli Studi della Campania Luigi Vanivitelli, 81031 Aversa, Italy; \\ ilaria.lombardi@unicampania.it \\ * Correspondence: liatrematerra@libero.it
}

\section{check for} updates

Citation: Sukaj, S.; Ciaburro, G.; Iannace, G.; Lombardi, I.; Trematerra, A. The Acoustics of the Benevento Roman Theatre. Buildings 2021, 11, 212. https://doi.org/10.3390/ buildings 11050212

Received: 9 March 2021

Accepted: 16 May 2021

Published: 19 May 2021

Publisher's Note: MDPI stays neutral with regard to jurisdictional claims in published maps and institutional affiliations.

Copyright: (c) 2021 by the authors. Licensee MDPI, Basel, Switzerland. This article is an open access article distributed under the terms and conditions of the Creative Commons Attribution (CC BY) license (https:// creativecommons.org/licenses/by/ $4.0 /)$

\begin{abstract}
During the Imperial Roman period, thousands of theatres were built. The theatres have three principal elements: the scene building (actor position), the orchestra and the cavea (spectator seating). The theatres were built without a roof, so they were open-air spaces. The theatres were abandoned afterward the barbarian invasions, and during the Middle Ages, homes were built inside the cavea. The theatres were rediscovered during the Renaissance period. Today, ancient theatres are the center of cultural events and are used for various kinds of shows. This work discussed the acoustics of the Roman theatre of Benevento, which was built during the Imperial Age. The theatre was destroyed after the barbaric invasion and it was rebuilt in the first half of the 1900s. The theatre was opened in 1957, and today it is the center of social and cultural activities. Acoustic measurements were carried out according to ISO 3382 standard, placing an omnidirectional sound source on the scene building and in the orchestra, with the measurement microphones along three directions in the cavea. The acoustic characteristics in various seating areas of the cavea were evaluated. Therefore, it possible to understand in which sectors of the theatre the acoustic characteristics are optimal for different types of theatrical performances.
\end{abstract}

Keywords: scene building; cavea; orchestra; Roman theatre; acoustic measurements; reverberation time; ISO 3382

\section{Introduction}

During the Imperial Roman period, thousands of theatres were built [1-3]. The theatres were built to entertain people and create venues for shows [4]. The theatre represented the symbol of the greatness of the city, and it was used for political meetings, satirical representations and comedies [5,6]. The best-preserved theatres are in Italy, Spain, France, Turkey and Jordan. The first theatres were built in Greece, with the cavea resting on the slope of a hill. At first, the cavea had linear steps, however later, the cavea was built with a concentric stepped structure to improve the vision and to allow a more optimal sound distribution, and the legend of the good acoustics of the Greek theatres was born. The principal elements of the ancient theatre are scene building, orchestra and cavea, as shown in Figure 1. The architect Vitruvius (1st century B.C.), in the tract called "De Architectura," described the geometrical theatres' characteristics. In the 5th book, the fundamental principles for achieving correct vision and for listening to the theatrical performances are introduced. There are a few simple rules to follow to obtain good acoustics inside theatres, for example, the edges of each step should be in a straight line from the first to the last seat to prevent the sound from finding obstacles during the propagation $[7,8]$. In this paper, the acoustic characteristics of the Roman theatre of Benevento, in its current state, are discussed. Benevento (South of Italy) was an important city during the Roman period, and the theatre was built in the second century A.D. The orchestra measured $20 \mathrm{~m}$ diameter, the cavea measured $90 \mathrm{~m}$ diameter, while scene building measured a width of $44 \mathrm{~m}$, with 
25 arcades on three levels [9]. The scene building (pit stage) had three open doors, and it was made up of two orders of columns with a sloped wooden roof. The height of the stage was $1.5 \mathrm{~m}$, so the spectators are able to see the actors on the scene building.

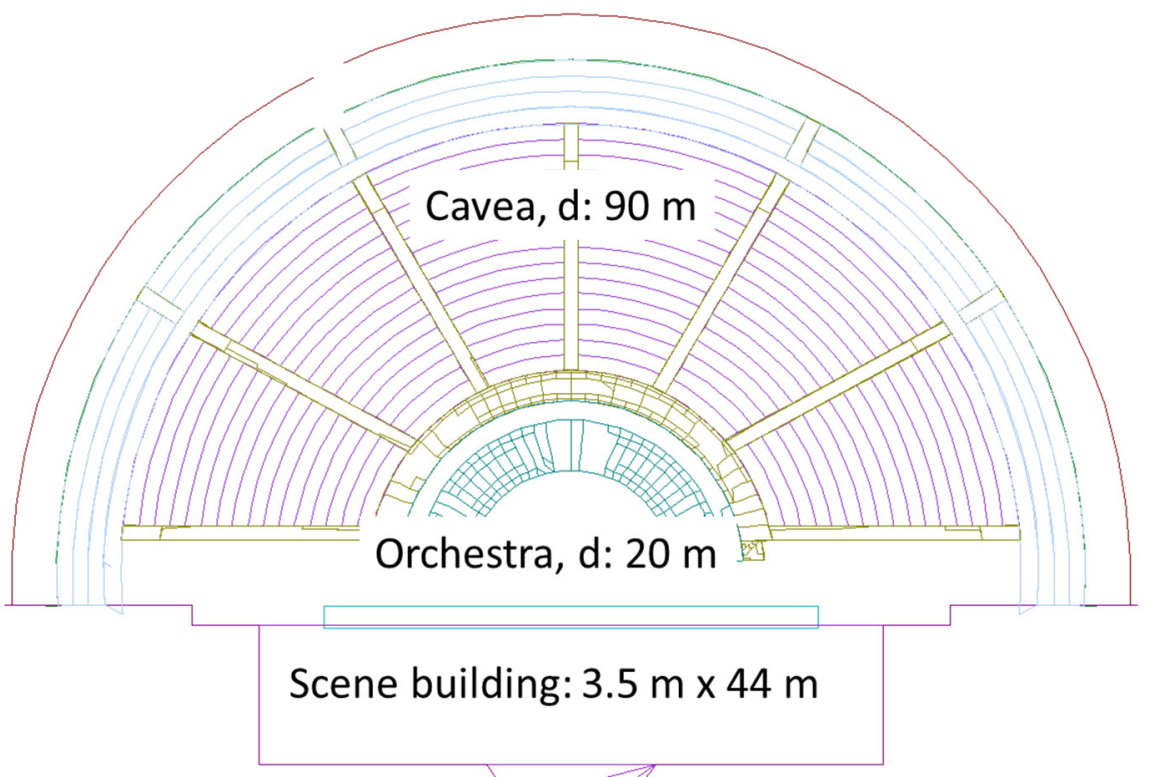

Figure 1. Theatre principal elements.

The scene building was the place where the actors performed and it contains the stage machines used to give movement to the theatrical representation. The cavea (the area where spectators sit) could contain over 10,000 spectators. To hold the greatest number of spectators, the cavea was divided in two elements: a lower part (ima cavea) and a higher part (summa cavea), divided by a walkway (diazoma) that allowed spectators to easily reach their seat.

The theatre was damaged by an earthquake in the year 346 [10], and it was no longer used after the advent of Christianity, which considered performances in theatres as pagan activities. In the Middle Age, houses were built inside the cavea. In the 18th century, the church "Santa Maria della Verità" was built on the right side of the cavea and it is still used [11]; therefore, the cavea is not acoustically symmetrical.

Figure 2 shows the ruins of the theatre in a painting of $1759 \mathrm{ca}$. (A. Joli, view of Queen Maria Amalia of Saxony in Benevento). The theatre had only a few external arcades and the first level was covered with earth, and houses were built inside the theatre. Figure 3 shows a picture of the early 1900s with the houses inside the cavea. During the restoration works, the houses inside the cavea were demolished and only the church remained. The cavea was rebuilt following the geometric rules described by Vitruvius, while the scene building was rebuilt with two lateral walls. The "ima cavea" was rebuilt with fifteen steps with terracotta bricks. The steps have the dimensions: height of $0.40 \mathrm{~m}$ and depth of 0.70 $\mathrm{m}$, with the cavea slope of $30^{\circ}$. The "summa cavea" was partially rebuilt. Figures 4 and 5 show the internal view in the current state, while Figures 6 and 7 show an aerial view.

After the end of the restoration works, the theatre was reopened on 26 June 1957, with a comedy of the ancient Greek (Ecclesiazusae or The Assembly women by Aristophanes). For security reasons, the maximum capacity is 1800 spectators. The theatre is used for different types of shows (prose, opera, jazz, music concert). Figure 8 shows the scene building during a performance in the summer season, while Figure 9 shows the orchestra and cavea during a performance. 


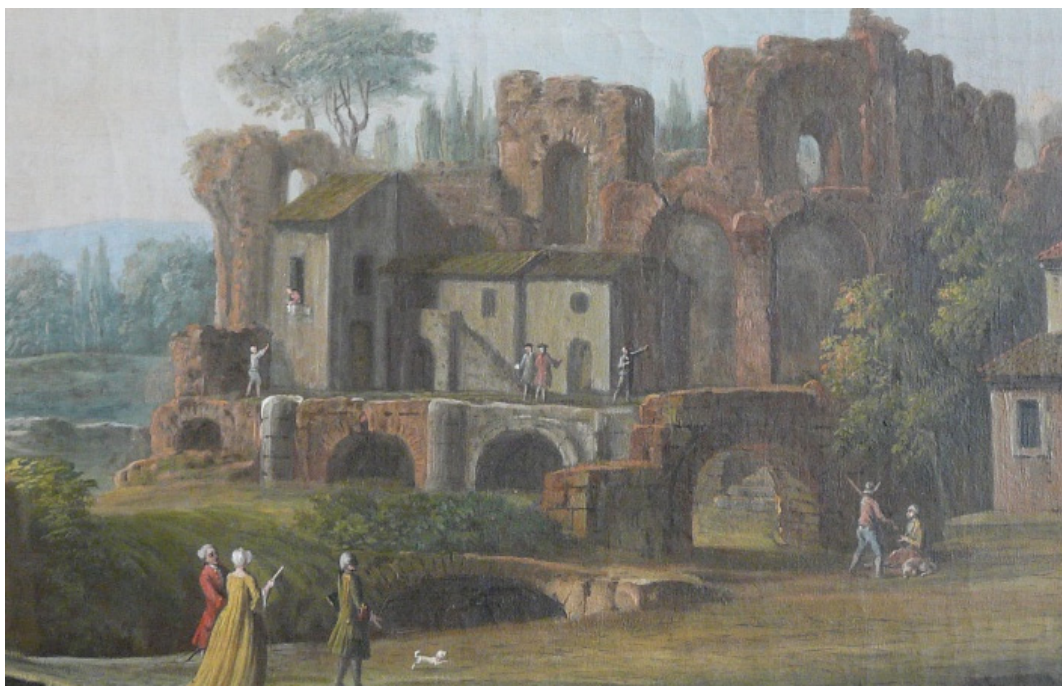

Figure 2. The ruins of the theatre in a painting in 1759 (A. Joli, view of Queen Maria Amalia of Saxony in Benevento).

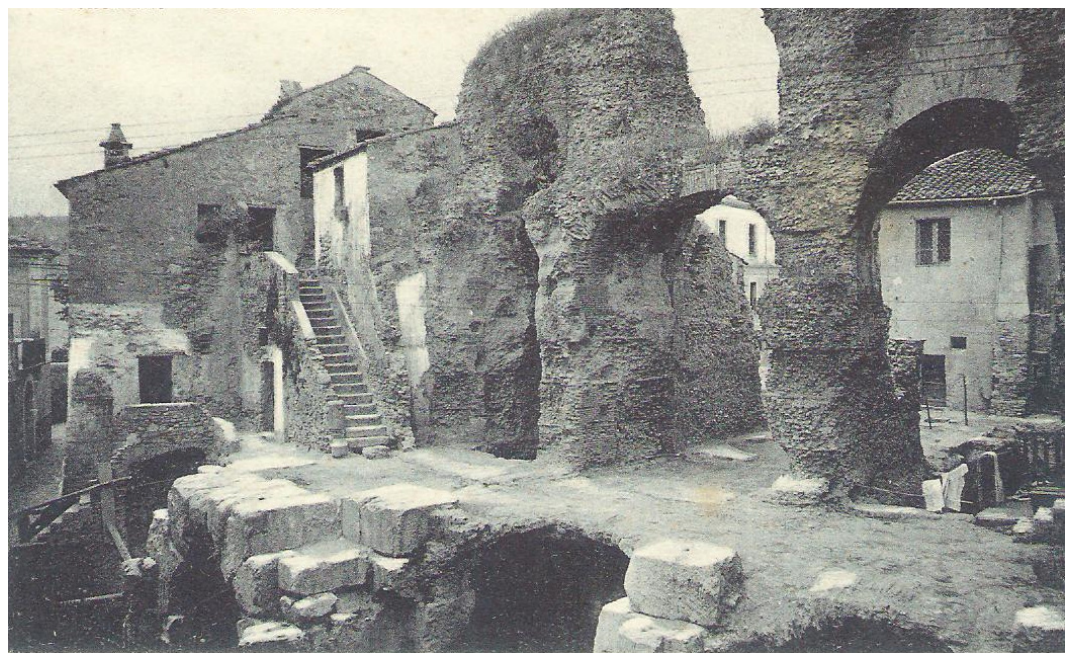

Figure 3. The houses inside the cavea at the beginning of the 1900s.

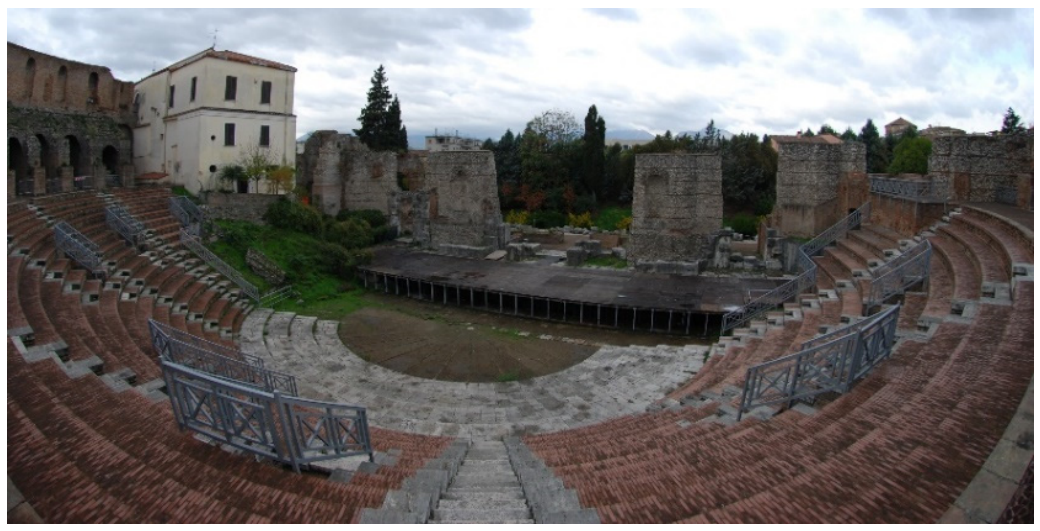

Figure 4. Scene building, orchestra, cavea and the church built on the cavea. 


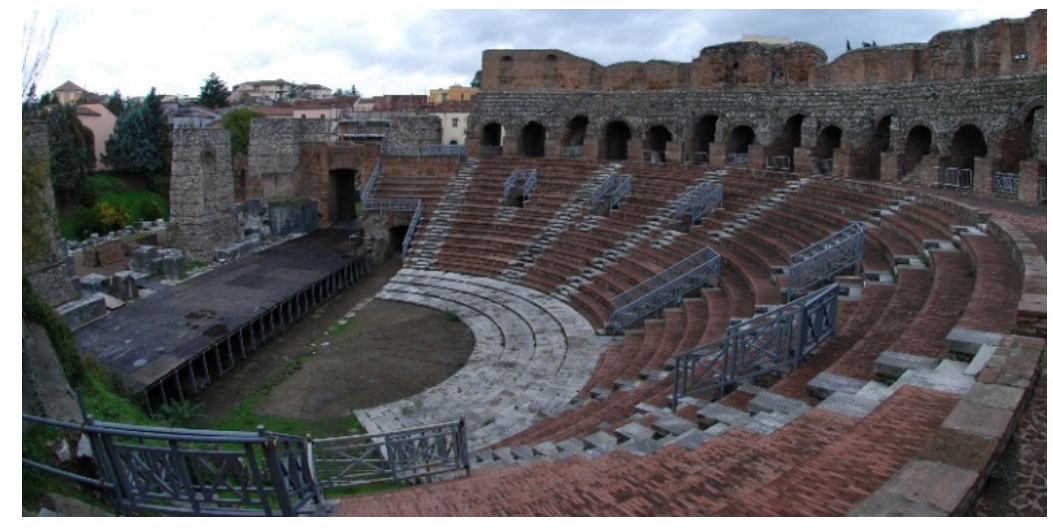

Figure 5. Scene building, orchestra and cavea.

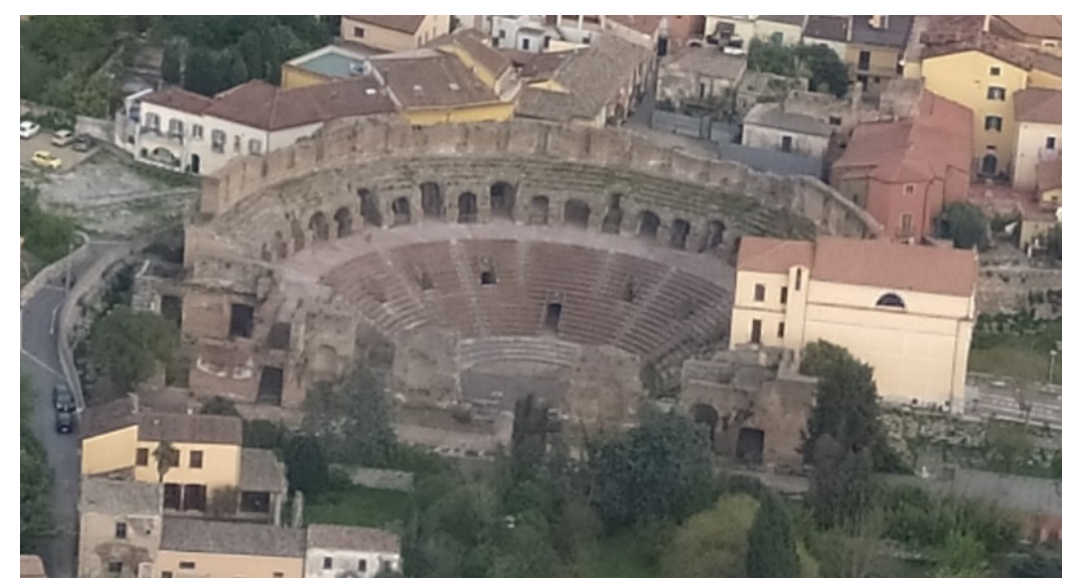

Figure 6. Aerial view: scene building, orchestra, cavea and the church built on the cavea.

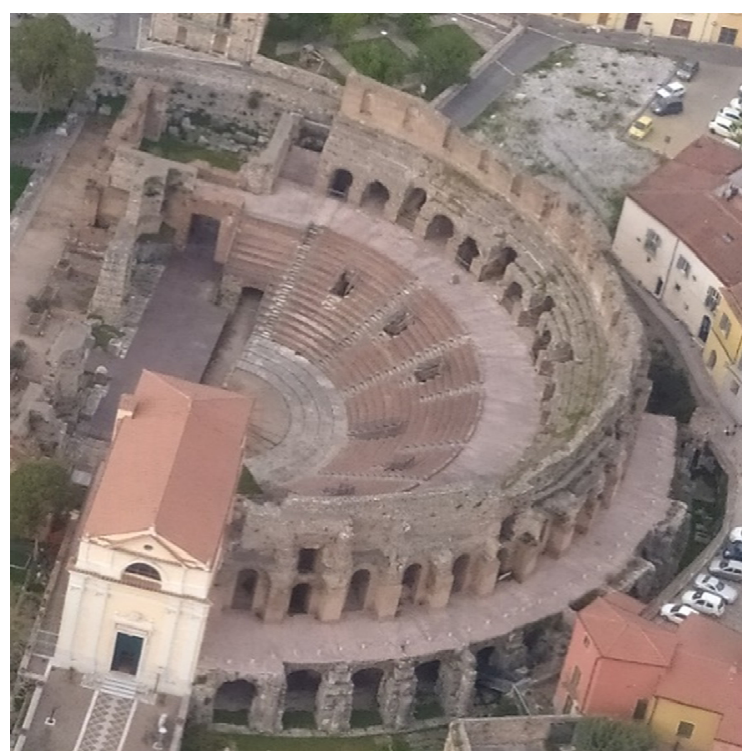

Figure 7. Aerial view: scene building, orchestra, cavea and the church built on the cavea. 


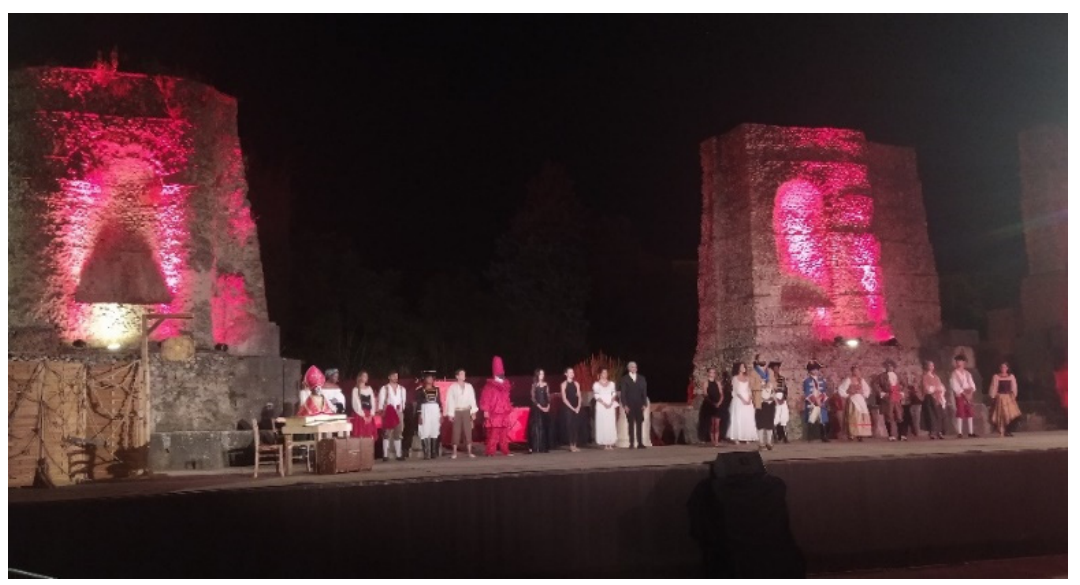

Figure 8. Scene building during a performance in the summer season.

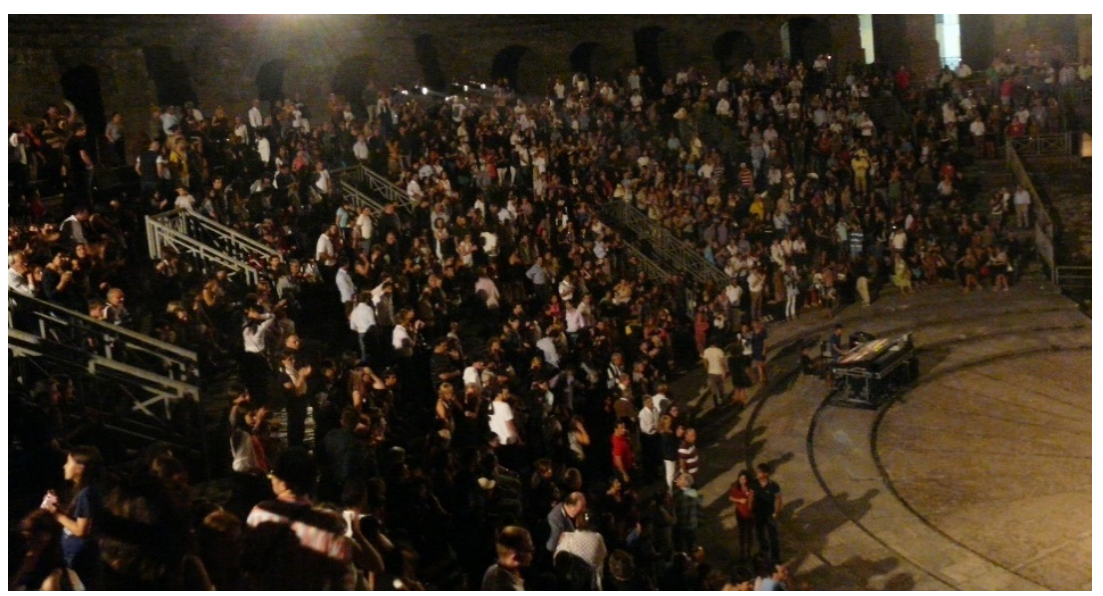

Figure 9. Orchestra and cavea during a performance.

\section{Acoustic Measurements}

The acoustic measurements provide information about the show performances when the actors are on the scene building and the musicians are in the orchestra [12-16]. The acoustic measurements were carried out with an omnidirectional sound source (type Peecker Sound mod. JA12) in accordance with the ISO 3382 standard [17-19]. The sound source was placed on the scene building and then in the orchestra: the source height from the floor was $1.60 \mathrm{~m}$, at the average height of an actor. The acquisition system was a Symphonie platform of $01 \mathrm{~dB}$ with MLS signal. MLS signals with order 16 and a length of $5 \mathrm{~s}$ feed the sound source. The impulse responses were detected by an omnidirectional microphone, type GRAS 40 AR $1 / 2^{\prime \prime}$. The microphones were placed in the cavea at a height of $0.8 \mathrm{~m}$, the average height of a seated audience. The microphone positions were along three radial directions in order to obtain the average values of the acoustic parameters. The monaural acoustic parameters were analyzed, such as the reverberation time (T30), the Early Delay Time (EDT), the clarity (C80), the definition (D50), the strength (G) and the STI for speech intelligibility, which provides a numerical value for speech transmission quality. STI is a numeric representation measure of speech intelligibility characteristics whose value vary from $0=$ bad to $1=$ excellent (Table 1 shows the STI scale) $[20,21]$. The acoustic measurements were carried out in empty condition without spectators, so the background noise was reduced; during the acoustic measurements, the background noise had a sound measurement level of $35 \mathrm{dBA}$. The theatre is located in old town, an area away from traffic roads. Acoustic measurements were carried out with a $01 \mathrm{~dB}$ sound level meter inside the orchestra on a tripod at a height of $1.6 \mathrm{~m}$ from the floor [22,23]. Figure 10 
shows the positions of the sound level meter inside the orchestra, during the background noise measurements.

Table 1. STI scale.

\begin{tabular}{cccccc}
\hline Quality & Bad & Poor & Fair & Good & Excellent \\
\hline STI & $0-0.3$ & $0.3-0.45$ & $0.45-0.6$ & $0.6-0.75$ & $0.75-1.0$ \\
\hline
\end{tabular}

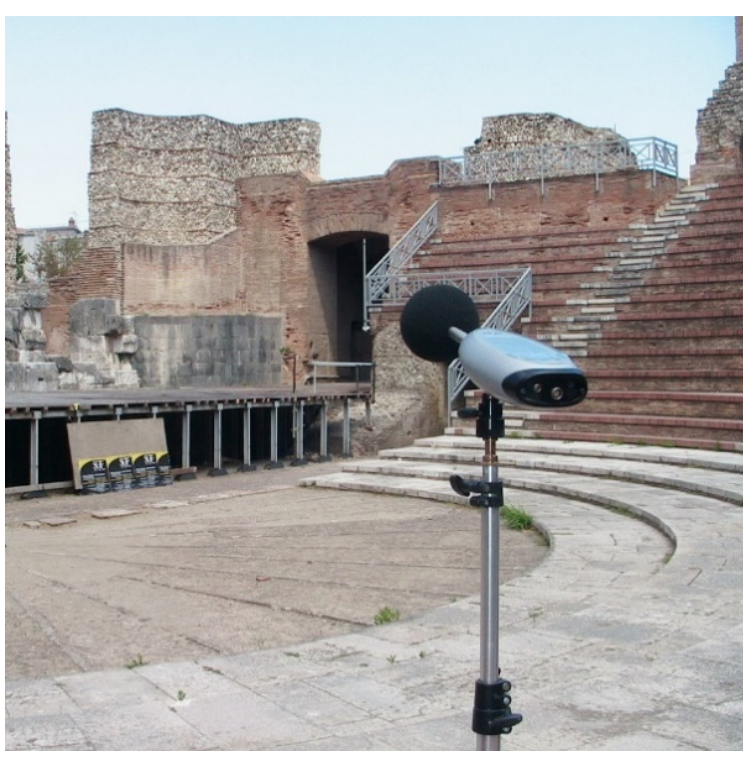

Figure 10. Positions of the sound level meter inside the orchestra, during the background noise measurements.

Through acoustic simulations with software for the architectural acoustics, it was possible to estimate the characteristics of ancient theatres in modern use. The acoustic characteristics do not change when the cavea is occupied by the audience. The theatre is an open space, so the absence of a roof allows a strong dispersion of the sound towards the outside. Furthermore, the portion of the cavea occupied by the audience is modest compared to the overall area of the theatre [24].

Figure 11 shows the positions of sound source (scene building and orchestra) and the positions of the twelve receivers in the cavea.

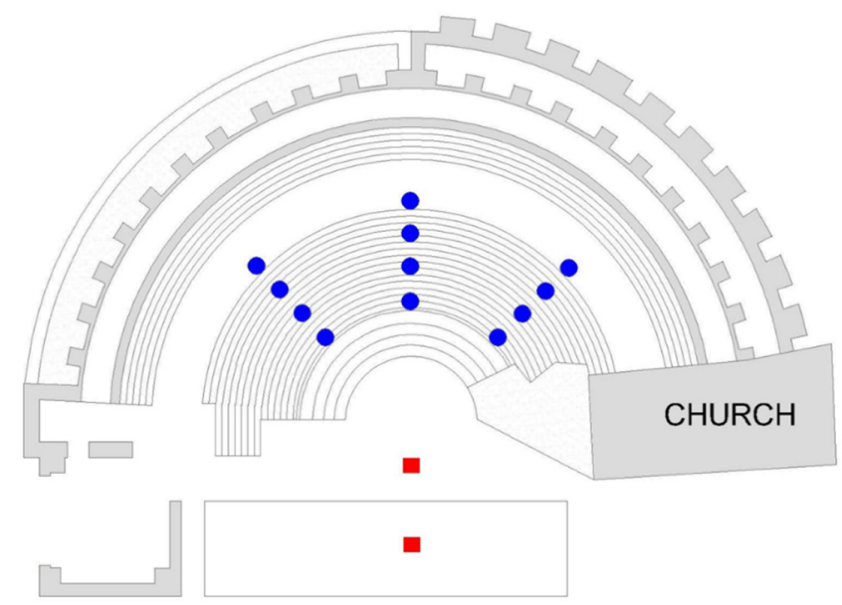

Figure 11. Positions of sound source (scene building and orchestra) and the positions of the receivers in the cavea. The squares in red indicate the position of the source, while the circles in blue indicate the positions of the receivers. 
Even if the ancient theatres are an open space without a roof and without significant reflective surfaces, the acoustic parameters for good listening conditions refer to closed theatres, and Table 2 shows the optimal values of the acoustic parameters in different performances (musical or speech) $[25,26]$.

Table 2. Optimal values of the acoustic parameters in different musical listening conditions or speech intelligibility.

\begin{tabular}{ccccc}
\hline Parameters & EDT, $\mathbf{s}$ & T30, $\mathbf{s}$ & C80, dB & D50 \\
\hline $\begin{array}{c}\text { Optimal values for musical } \\
\text { performances }\end{array}$ & $1.8<$ EDT $<2.6$ & $1.6<$ T30 $<2.2$ & $-2<$ C80 $<2$ & $<0.5$ \\
\hline $\begin{array}{c}\text { Optimal values for speech } \\
\text { performances }\end{array}$ & 1.0 & $0.8<$ T30 $<1.2$ & $>0.5$ \\
\hline
\end{tabular}

Referring to the position of the sound source in the orchestra and on the scene building, Figure 12 shows the average measured values of the acoustic parameters: EDT, T30, D50 and C80, in the octave band frequencies from $125 \mathrm{~Hz}$ to $4000 \mathrm{~Hz}$, in accordance with the ISO 3382 standard [27-29]. The measured average values show the synthesis of the twelve measurements obtained in the cavea.
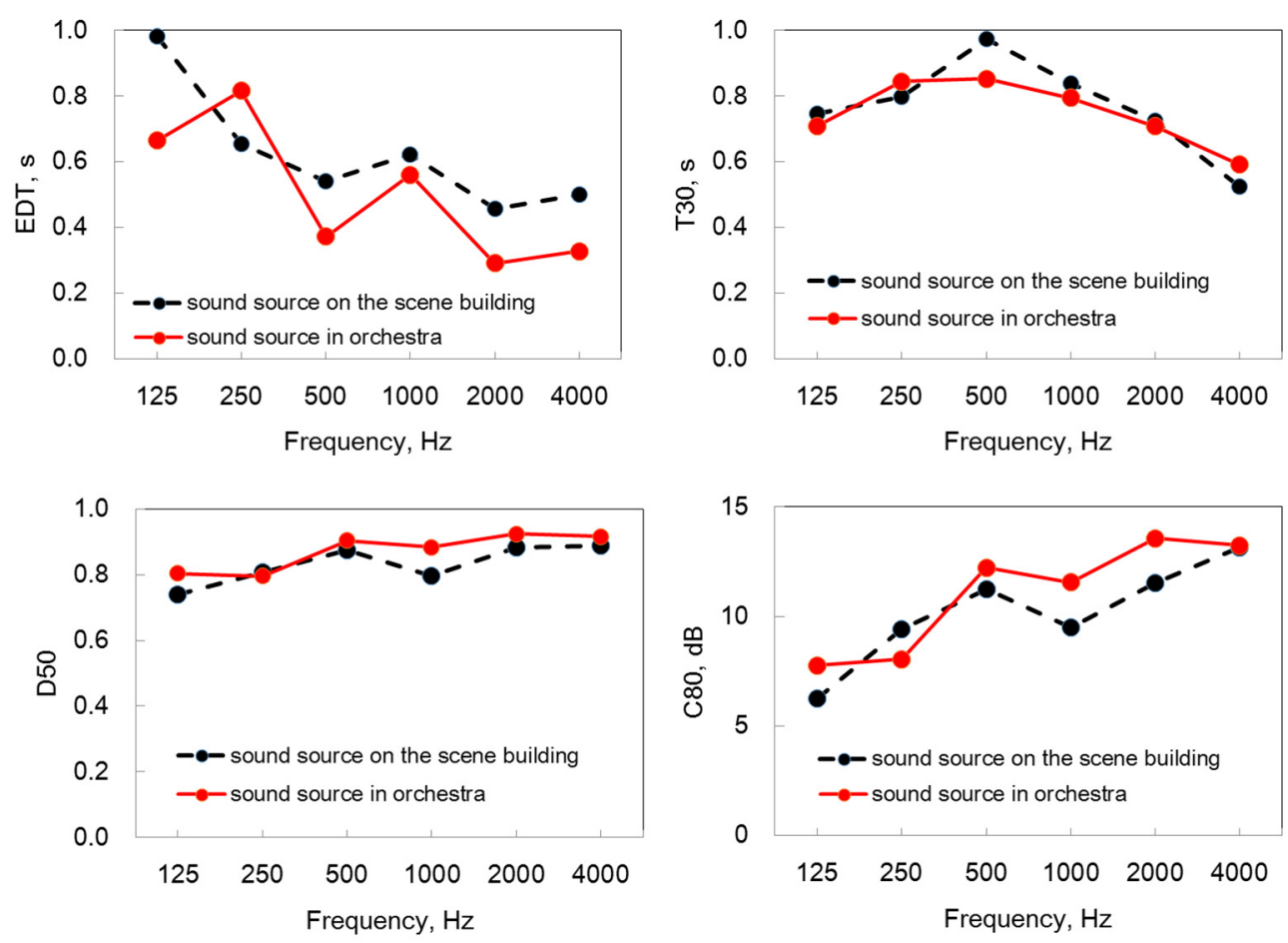

Figure 12. Average measured values of acoustic parameters: EDT, T30, D50 and C80 in the octave band frequencies from $125 \mathrm{~Hz}$ to $4000 \mathrm{~Hz}$.

In open-air theatres, the parameter $\mathrm{G}$ (strength, $\mathrm{dB}$ ) assumes a special significance for the assessment of acoustic characteristics. This parameter is defined in the ISO 3382 standard. $\mathrm{G}$ (strength, $\mathrm{dB}$ ) is the gain from the sound pressure level, which is produced by the same omnidirectional sound source, with the same power level (Lw), in a free field at a distance of $10 \mathrm{~m}$ from the sound source. To measure the acoustic parameter $\mathrm{G}$, the omnidirectional sound source was calibrated measuring the sound power level $\mathrm{Lw}$ $(\mathrm{dB})$. The sound power level Lw was measured through the "substitution method" with a reference sound source. The procedure consists of a comparison of the sound pressure level, in octave band, of the source under test with those of the calibrated reference sound 
source. The reference sound source consists of a centrifugal fan driven by a powerful asynchronous motor, type B\&K 4204. The calibration procedures were carried out in a closed large room, and then the set-up was preserved. With the same "calibration" Lw set-up, the omnidirectional sound source was fed during the acoustic measurements in the theatre. The acoustic parameter $\mathrm{G}$ (strength, $\mathrm{dB}$ ) was calculated with the following formula: $G=L p-L w+31(d B)$, where $L p(d B)$ is the sound pressure level detected in the cavea in twelve positions. $\mathrm{Lw}(\mathrm{dB})$ is the sound power level of the omnidirectional sound source $[30,31]$. Table 3 shows the $\mathrm{Lw}(\mathrm{dB})$ values of the omnidirectional sound source measured.

Table 3. Lw (dB) sound power level of the omnidirectional sound source measured.

\begin{tabular}{ccccccc}
\hline Frequency, $\mathrm{Hz}$ & 125 & 250 & 500 & 1000 & 2000 & 4000 \\
\hline $\mathrm{Lw}, \mathrm{dB}$ & 92 & 102 & 98 & 97 & 103 & 105 \\
\hline
\end{tabular}

Figure 13 shows the average values of the strength $(G, d B)$ measured in the cavea, when the sound source is placed on the scene building and in the orchestra. Figure 13 shows the average values of the strength $(\mathrm{G}, \mathrm{dB})$ as a function of the distance from sound source to receivers, and it is a Gmid value obtained as the average of $\mathrm{G}$ for the middle frequencies at 500, 1000 and $2000 \mathrm{~Hz}$ in octave bands. The strength $(\mathrm{G})$ values are negative, and they are comparable to similar acoustic measurements in Greek and Roman theatres [32,33]. The Benevento Roman theatre in its current state has insufficient conditions for performing events such as opera or speech alone.

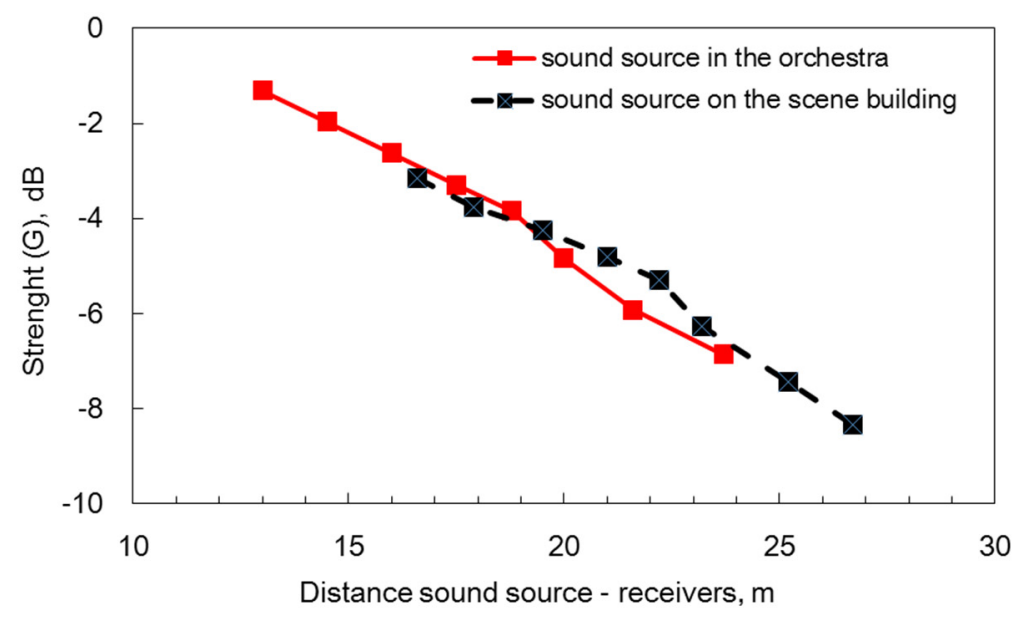

Figure 13. Average values of the strength $(\mathrm{Gmid}, \mathrm{dB})$ as a function of the distance from sound source to receivers, with sound source on the scene building and in the orchestra.

The singer's voice cannot be appreciated by the spectators sitting in the cavea, because the music listened to is "dry", that is, it lacks reflections that enrich the sense of reverberation and therefore of quality. Furthermore, this effect becomes even more negative due to the distance between the cavea and the scene building. In fact, the spectators seated in the last rows complain of a low strength in the singers' voice during the opera, so it would not be wrong to use sound-amplification systems.

Figure 14 shows the average values of the strength $(G, d B)$ in frequency function (octave bands) from $125 \mathrm{~Hz}$ to $4000 \mathrm{~Hz}$, with sound source on the scene building and in the orchestra. The strength $(\mathrm{G}, \mathrm{dB})$ values, in the frequency domain, are greater, as expected, for the position of the sound source in the orchestra. 


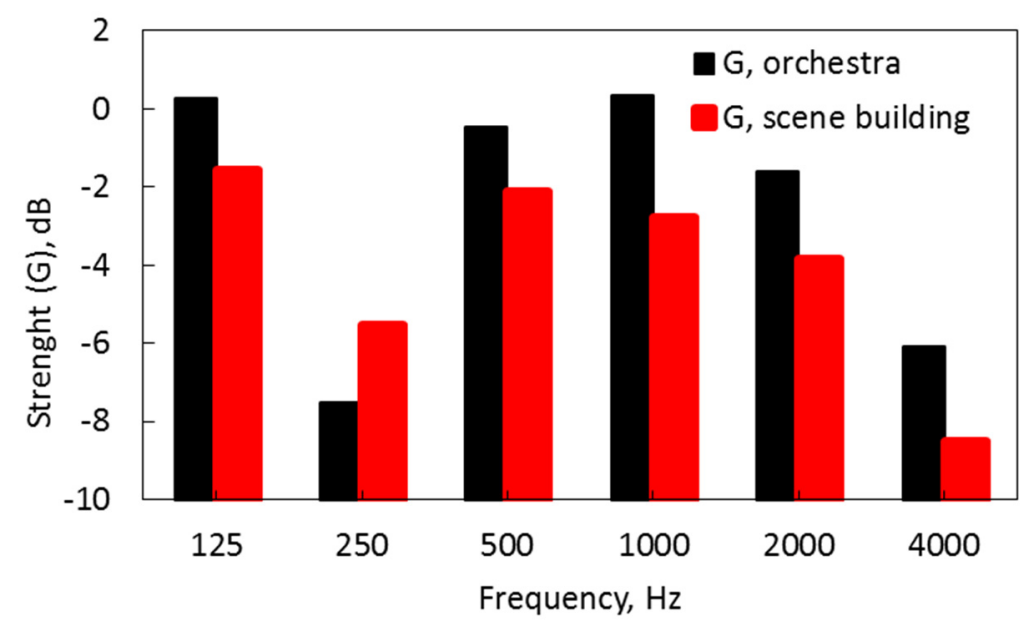

Figure 14. Average values of the strength $(\mathrm{G}, \mathrm{dB})$ in frequency function (octave bands) with sound source on the scene building and in the orchestra.

\section{Discussion}

The acoustic measurements show values of reverberation time (T30) equal to $1.0 \mathrm{~s}$ (Figure 12). The insufficient effects of sound reflections means that the actors or singers voices arrive weakly on the steps of the cavea. With the sound source in the orchestra, the values of the measured reverberation time (T30) were lower at middle frequencies. Early Delay Time (EDT) parameters (Figure 12) are smaller due to the absence of reflective surfaces at the scene building and other architectural elements. The parameter clarity (C80) for musical performances is considered (Figure 12). The optimum range for symphony concerts for objective clarity (C80) appears to be between -2 and $+2 \mathrm{~dB}$, which is far from the values for good listening for musical performances. While the acoustic measurement values (C80) are equal $10 \mathrm{~dB}$, the parameter definition (D50) (Figure 12) is over 0.8, so in accordance with Table 2, the theatre has good characteristics for speech performances. The average values of STI are excellent, in fact STI is equal to 0.81 with sound source on the scene building and STI is equal to 0.84 with sound source in the orchestra. The theatre has good acoustic characteristics for understanding speech; in fact, it is good in every point of the cavea. The reverberation time (T30) increases at the frequency of $500 \mathrm{~Hz}$. This effect is due to the reflections of the sound waves on the steps. The steps dimensions are height equal to $0.40 \mathrm{~m}$, and depth equal to $0.70 \mathrm{~m}$. At the frequency of $500 \mathrm{~Hz}$, the wavelength $(\lambda)$ is equal to $0.7 \mathrm{~m}$, the dimension of step depth, so at this frequency, there is an effect of sound amplification as the reverberation time increases. The ancient theatres were famous for their "good acoustics". Many scientists have investigated this legend and many papers have been written. The secret of good acoustics is linked to the diffusion of sound on the steps-the tiers are regular surfaces that allow a good diffusion of the sound and therefore to obtain good acoustic performances [34,35]. In order to assess the acoustic characteristics of the Roman theatre of Benevento in the actual configuration, a comparison was conducted with the acoustic parameters measured in empty conditions in the open-air theatres of Pompeii (large theatre and Odeon), Cassino, Posillipo, Taormina, Segesta and Siracusa [36-39]. The average values of the monaural parameters at the mid-frequency bands of $500 \mathrm{~Hz}$ and $1000 \mathrm{~Hz}$ are reported in Table 4. From the comparison with the other reconstructed open-type theatres, the Benevento Roman theatre does not have the shortest reverberation time. The acoustic parameters are comparable to those measured in other open space theatres. 
Table 4. Acoustic parameters averaged at mid-frequency bands of $500 \mathrm{~Hz}$ and $1000 \mathrm{~Hz}$ measured in some ancient theatres in empty conditions.

\begin{tabular}{ccccc}
\hline Theatres & T30 (s) & C80 (dB) & D50 (-) & Cavea Diameter $(\mathbf{m})$ \\
\hline Benevento & 0.9 & 8.0 & 0.78 & 90 \\
Cassino & 0.6 & 19.0 & 0.91 & 53 \\
Pompeii (large theatre) & 0.9 & 6.0 & 0.70 & 60 \\
Pompeii (Odeon) & 1.0 & 9.5 & 0.8 & 30 \\
Posillipo & 1.1 & 3.0 & 0.70 & 47 \\
Taormina & 1.9 & 1.17 & 0.53 & 110 \\
Segesta & 0.5 & 16.0 & 0.90 & 140 \\
Siracusa & 1.2 & 13.0 & 0.90 & \\
\hline
\end{tabular}

To better understand the acoustic behavior of the theatre, starting from the data measured in the cavea (12 measurement points along three radial directions), a map of the average spatial distribution of the acoustic parameters was obtained by means of simply tracing the level lines. The acoustic parameter analyzed are C80, STI and T30.

Figure 15 shows the spatial distribution of $\mathrm{C} 80(\mathrm{~dB})$ measured values at the frequency of $1000 \mathrm{~Hz}$, when the sound source is on the scene building. The points of the cavea closest to the scene building have a higher value of $\mathrm{C} 80$, while in the upper right area of the cavea, the $\mathrm{C} 80$ value tends to decrease. However, the value of $\mathrm{C} 80$ does not present optimal conditions for listening to music. Figure 16 shows the spatial distribution of C80 (dB) measured values at the frequency of $1000 \mathrm{~Hz}$, when the sound source is in the orchestra. Additionally, in this configuration, the points of the cavea closest to the scene building have a higher value of $\mathrm{C} 80$, while $\mathrm{C} 80$ decreases in an area at the top of the cavea (blue area) by the effects of the sound reflections due to the presence of the church walls.

Figure 17 shows the spatial distribution of STI (speech transition index) measured values when the sound source is on the scene building, while Figure 18 shows the spatial distribution of STI (speech transition index) measured values when the sound source is in the orchestra. Generally, in open space theatres in the original configuration, the values of the STI were greater in the central area of the cavea, which is due to the geometrically symmetrical structure of the theatre. Today, the theatres are renovated, and the symmetry is not maintained, as in the case of the Roman theatre of Benevento. In fact, the cavea irregular geometry leads to effects of irregular distribution of the sound. The values of STI in both configurations are not uniform, with significant variations inside the cavea. The values of STI change between 0.90 and 0.75 . The theatre has excellent performances for listening to speech. The voice quality listening changes from point to point, but in every area of the cavea, the speech comprehension is good.

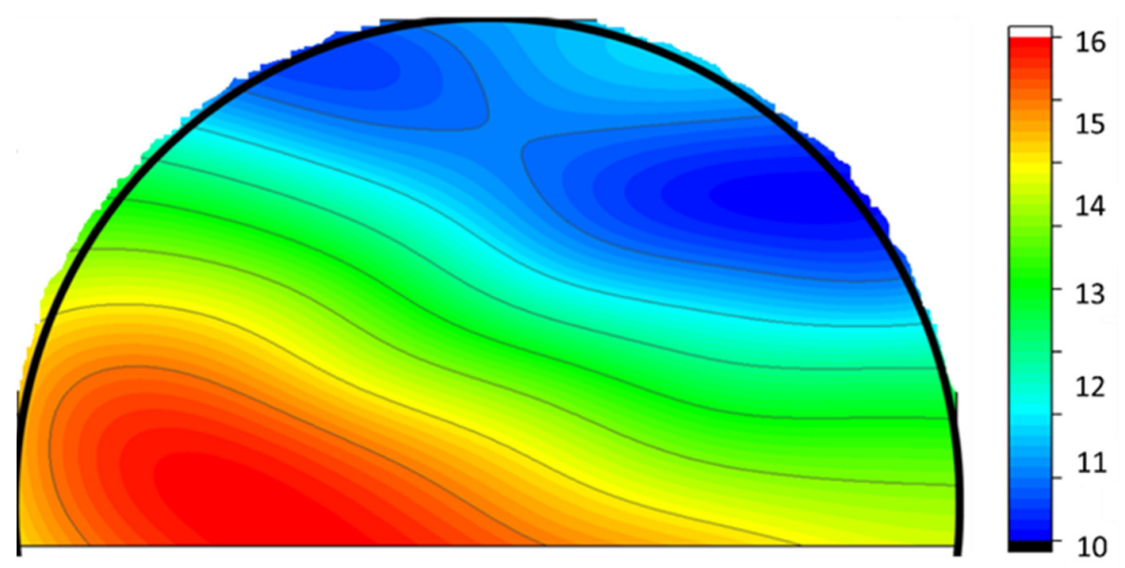

Figure 15. Sound source on the scene building. Spatial distribution of $\mathrm{C} 80(\mathrm{~dB})$ at the frequency of $1000 \mathrm{~Hz}$. 


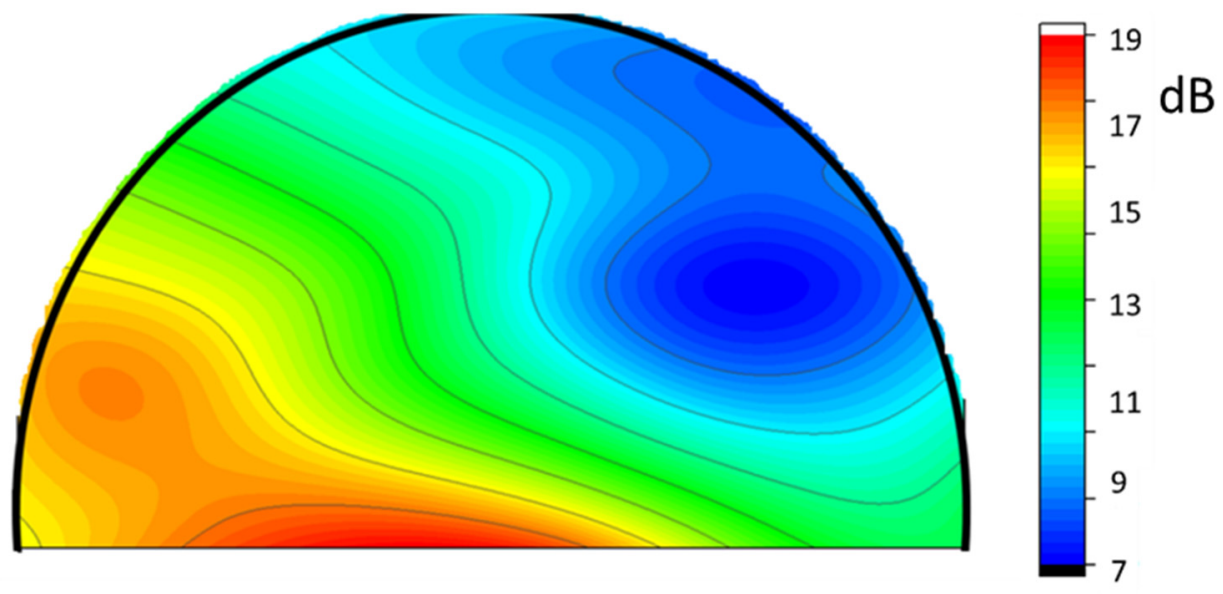

Figure 16. Sound source in the orchestra. Spatial distribution of C80 (dB) at the frequency of $1000 \mathrm{~Hz}$.

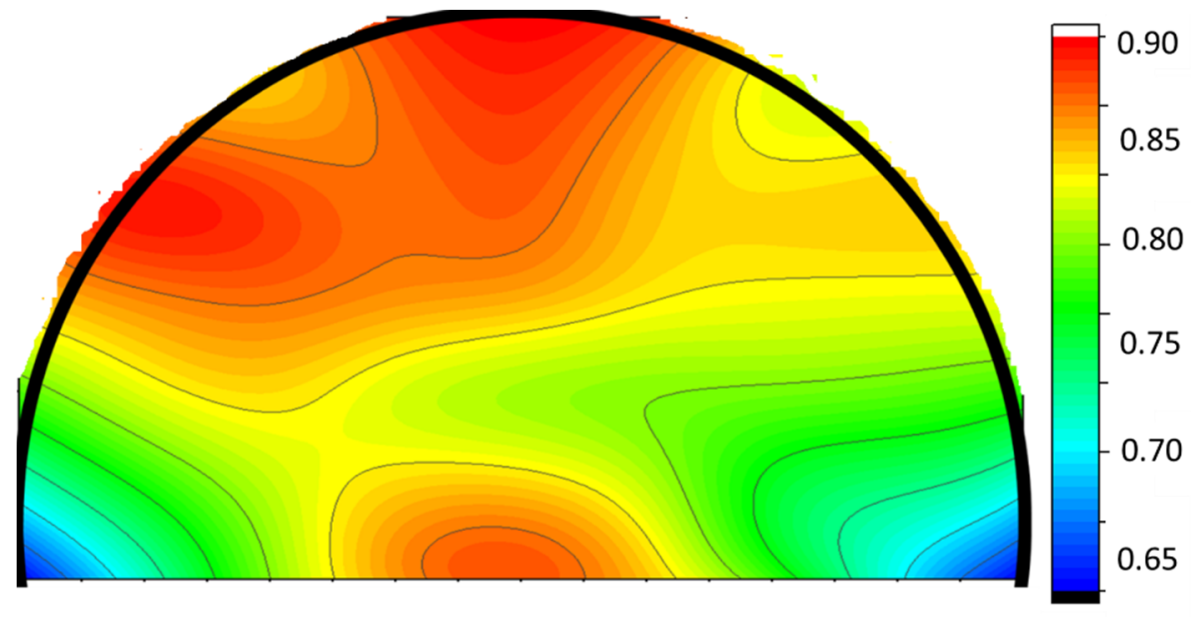

Figure 17. Sound source on the scene building. Spatial distribution of STI.

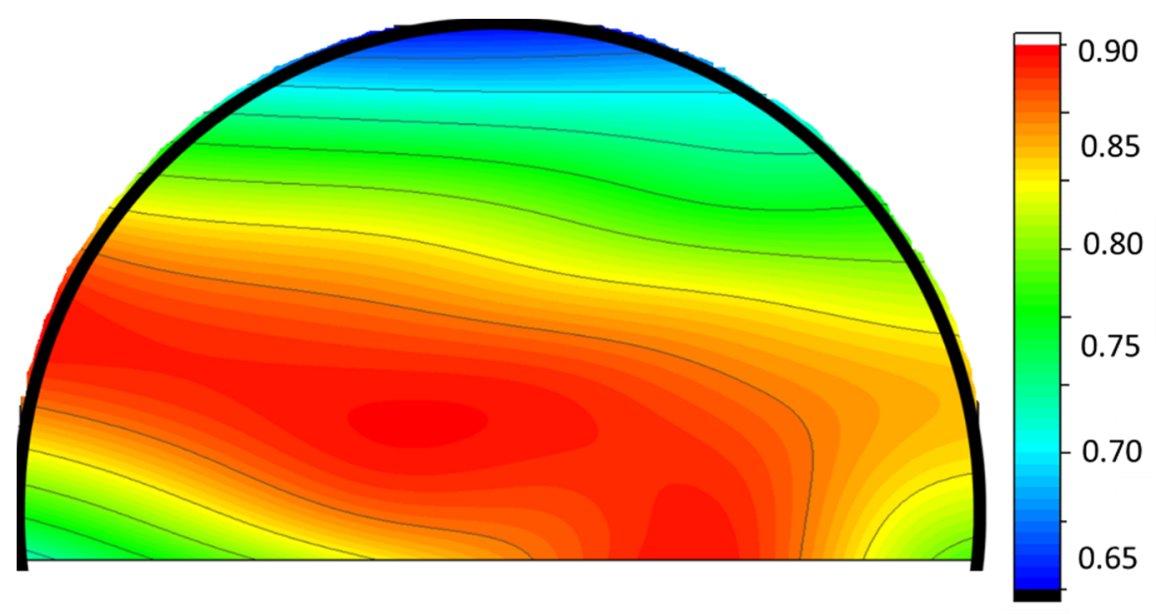

Figure 18. Sound source in the orchestra. Spatial distribution of STI.

Figure 19 shows the spatial distribution of T30 (s) reverberation time measured values when the sound source is on the scene building. The values of T30 are higher in the right area of the cavea $(\mathrm{T} 30=0.90 \mathrm{~s})$, while in left area, $\mathrm{T} 30$ decreases $(\mathrm{T} 30=0.75 \mathrm{~s})$. Figure 20 shows the spatial distribution of T30 (s) reverberation time measured values when the 
sound source is in the orchestra. In this configuration, the trend of T30 follows the geometric distribution of the steps of the cavea. The reverberation time values are equal to $1.0 \mathrm{~s}$ due to the absence of the scene building and other reflecting surfaces.

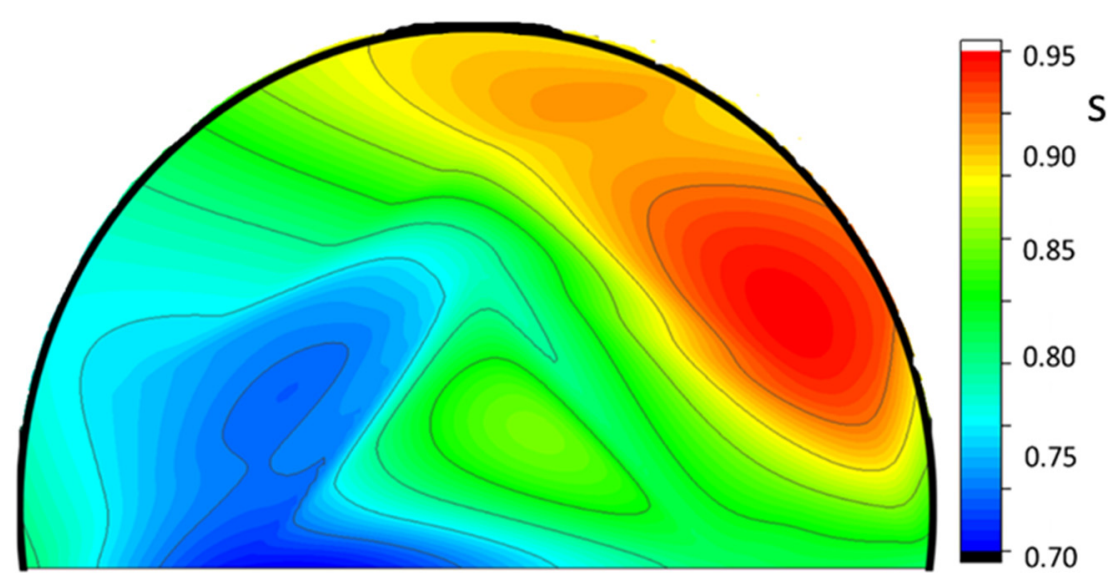

Figure 19. Sound source on the scene building. Spatial distribution of $\mathrm{T} 30$ (s) at the frequency of $1000 \mathrm{~Hz}$.

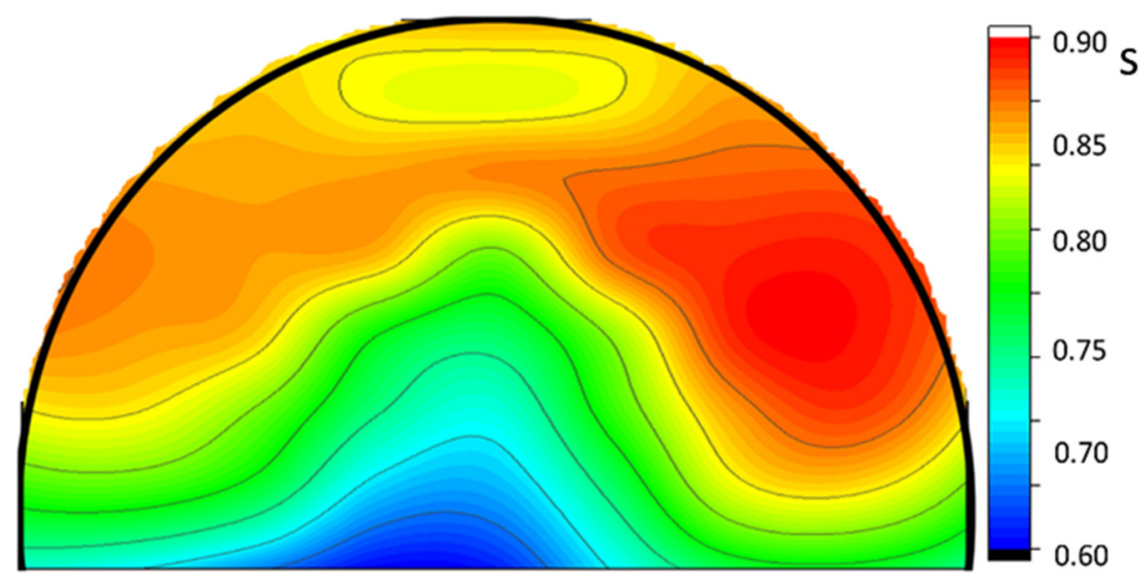

Figure 20. Sound source in the orchestra. Spatial distribution of T30 (s) at the frequency of $1000 \mathrm{~Hz}$.

The theatre, in its current configuration, is not symmetric, the scene building is partly rebuilt, and the central area is empty. The "summa cavea" was partially rebuilt. In the upper part of the cavea, the closing wall was partially rebuilt. The church (built in the 18th century) occupied the right area of the cavea. These non-symmetrical geometries lead to non-symmetrical acoustic characteristics inside the theatre.

Figure 21 shows the measured impulse response value, when the sound source is on the scene building, while Figure 22 shows the measured impulse response value when the source is in the orchestra and the measurement microphone is on the octave step of the cavea (halfway of the cavea). For both configurations, the impulse response is composed of a succession of sound reflections. The first impulse is due to the direct sound, and the second impulse is due to the sound reflection on the orchestra floor. Then, the steps of the cavea produce multiple reflections that contribute to the reinforcement of the direct sound. 


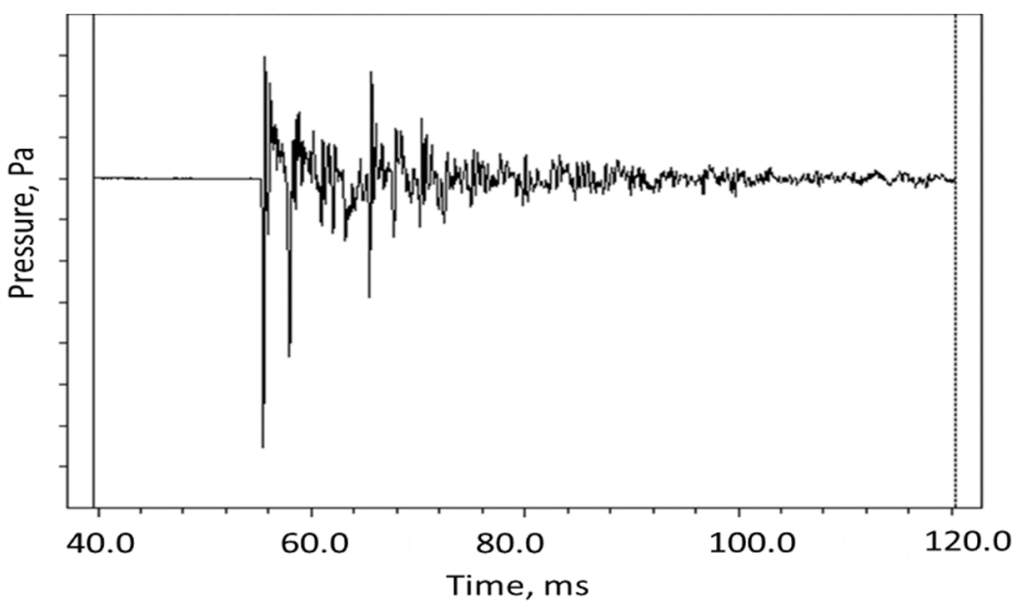

Figure 21. Sound source on the scene building: impulse response value obtained when the microphone is on the octave step of the cavea.

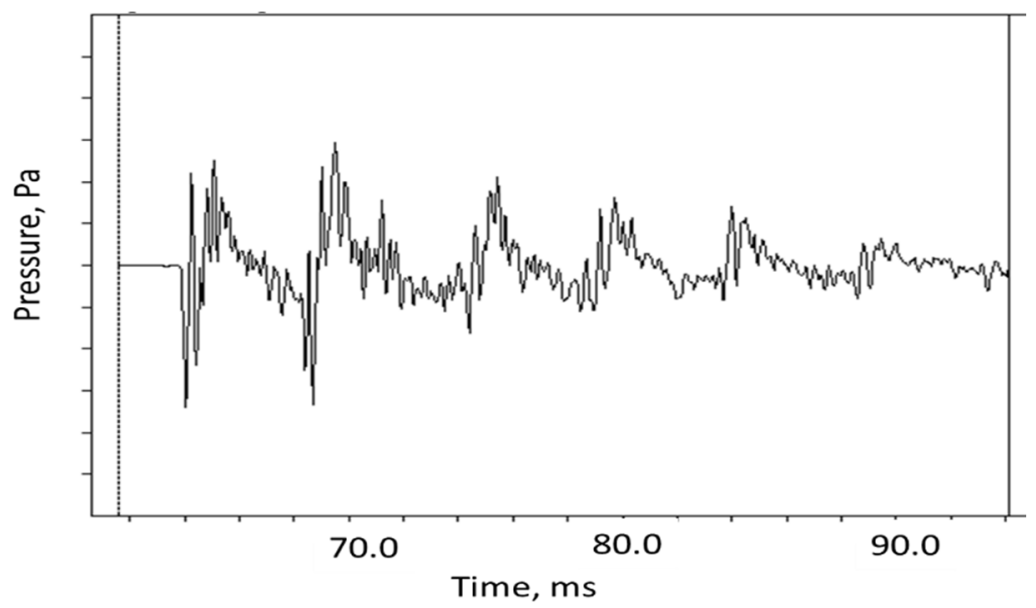

Figure 22. Sound source in the orchestra: impulse response value obtained when the microphone is on the octave step of the cavea.

When the sound source is placed in the orchestra, Figure 23 shows the values of sound pressure level (Lp, dBA) for six different microphone points in the cavea at the sixth row, while Figure 24 shows the values of sound pressure level at the fourteenth row. The value of the sound pressure level (Lp, dBA) is higher on the right area of the cavea than the left area. This effect is due to the sound reflections on walls of the church built on the right side of the cavea, so the theatre is not acoustically symmetric [40-42].

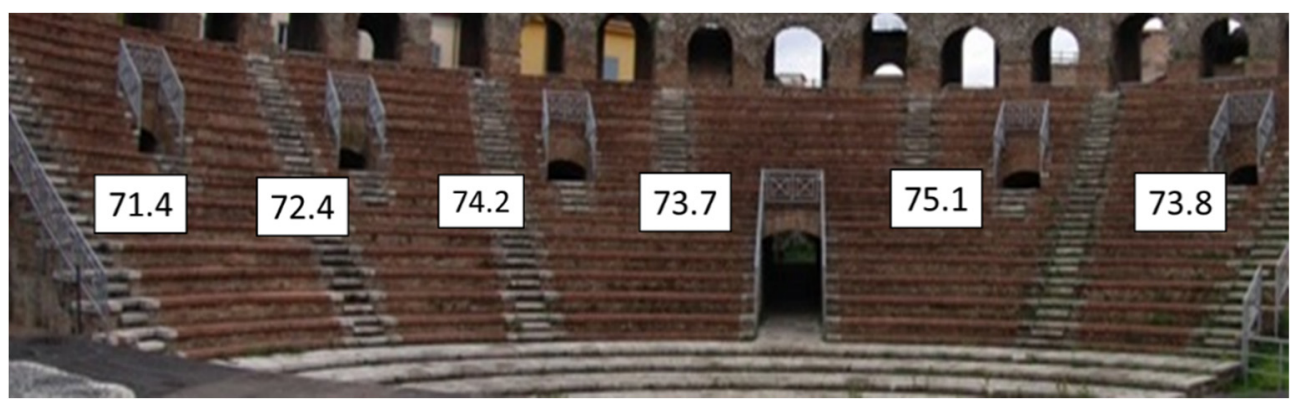

Figure 23. Sound pressure level (Lp, dBA) at row six, with sound source in the orchestra. 


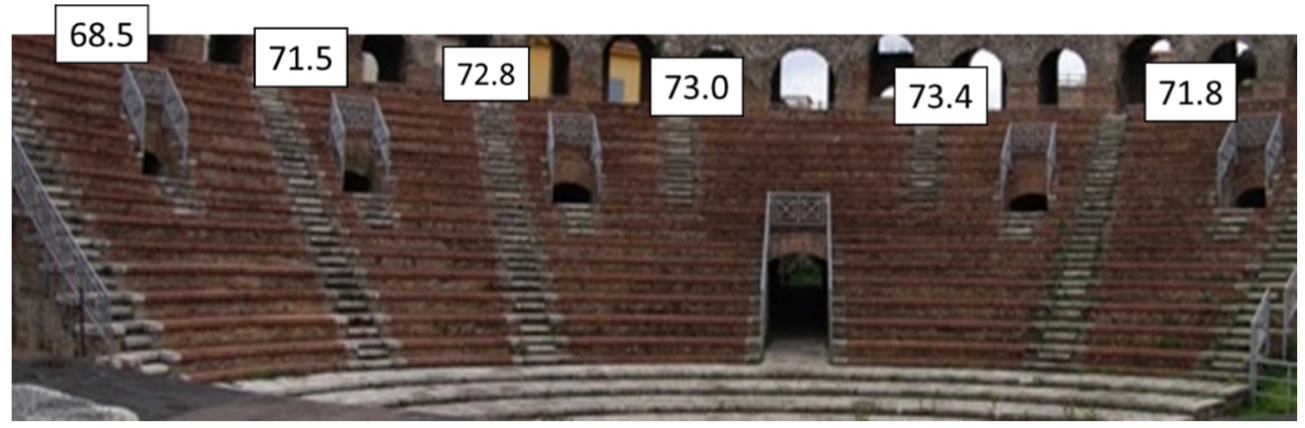

Figure 24. Sound pressure level (dBA) at row 14, with sound source in the orchestra.

\section{Conclusions}

In this paper, the acoustic characteristics of the Roman theatre of Benevento were reported. The theatre was built during the Imperial Period, when Benevento was an important city along the Appia road that connects Rome with Brindisi. The theatre was destroyed during the barbarian invasions and was only rebuilt in 1900. Today, the theatre is a cultural attraction, and during the summer seasons inside the theatre, there are numerous artistic performances. One of the advantages of the Roman theatre of Benevento is the fact that although it is located in the center of the old town, it is far from the traffic lines, so background noise levels inside the theatre are very low ( $35 \mathrm{dBA})$, and the effect of wind blow is negligible. In fact, background noise and wind are important factors for the speech intelligibility inside open space theatres. The analysis of the acoustic measurements showed us that the reverberation times do not exceed $1.0 \mathrm{~s}$ and the measured values of STI are high. The theatre lacks reflective surfaces that provide good acoustics for musical performances. Therefore, the theatre could be used for prose, but not for lyric or symphonic music, because there are no sound reflections that improve the music. A possible solution to improve the acoustics would be the installation of temporary structures of high-density PVC rigid sheets with reflective characteristics so that the sound incident on the sheets can be sent back into the cavea. The theatre has few sound reflections, and for its current use, all the events involve the use of sound amplification with loudspeakers. Despite the insufficient acoustics and the use of sound amplification systems, ancient theatres in modern use are appreciated by the public for the incomparable scenery that is created, where nature and art create a unique and suggestive environment for shows.

Author Contributions: Conceptualization, S.S., G.I., G.C. and A.T.; methodology, G.I., G.C. and A.T.; investigation, G.I., G.C. and A.T.; measurements G.I., G.C., I.L. and A.T.; software G.I., G.C., I.L. and A.T.; post-processing data, S.S., G.I., G.C. and A.T.; data curation, S.S., G.I., G.C., I.L. and A.T.; writing-original draft preparation, S.S., G.I., G.C., I.L. and A.T.; writing-review and editing, S.S., G.I., G.C., I.L. and A.T.; visualization, G.I., G.C. and A.T.; supervision, G.I., G.C. and A.T.; references study, S.S., G.I., G.C., I.L. and A.T. All authors have read and agreed to the published version of the manuscript.

Funding: This research received no external funding.

Conflicts of Interest: The authors declare no conflict of interest.

\section{References}

1. Zanker, P. La Città Romana; Laterza: Bari, Italy, 2013.

2. Sear, F. Roman Theatres: An Architectural Study; OUP Oxford: Oxford, UK, 2006.

3. Izenour, G.C. Theatre Design; McGraw-Hill: New York, NY, USA, 1977.

4. Savarese, N. In Scaena. Il Teatro di Roma Antica; Electa: Milan, Italy, 2007.

5. Wiles, D. Greek Theatre Performance: An Introduction; Cambridge University Press: Cambridge, MA, USA, 2000.

6. Arnott, P. An Introduction to the Greek Theatre; Springer: Berlin/Heidelberg, Germany, 1991.

7. Sabine, W.C. Collected Papers on Acoustics; Cambridge Harvard University Press: Cambridge, MA, USA, 1923. 
8. Vitruvio, M.P. De Architectura; Priestley and Weale: London, UK, 1826.

9. Iannace, G.; Trematerra, A. The rediscovery of Benevento Roman Theatre Acoustics. J. Cult. Herit. 2014, 15, 698. [CrossRef]

10. Boschi, E. Catalogo Parametrico dei Terremoti Italiani. Bologna, Italy, 1999. Available online: https://emidius.mi.ingv.it/CPTI/ (accessed on 18 May 2021).

11. Meomartini, A. Storia dei Monumenti Della Città di Benevento; Ristampa, Ricolo editore: Benevento, Italy, 1989.

12. Canac, F. L'acoustique des Theatres Antiques. Ses Enseignements; Editions du centre national de la recherche scientifique: Paris, French, 1967.

13. Ciaburro, G.; Iannace, G.; Lombardi, I.; Trematerra, A. Acoustic design of ancient buildings: The odea of Pompeii and Posillipo. Buildings 2020, 10, 224. [CrossRef]

14. Berardi, U.; Ciaburro, G.; D'Orazio, D.; Trematerra, A. The evolution of the acoustics of a medieval church. Can. Acoust.-Acoust. Can. 2020, 48, 14-16.

15. Ciaburro, G.; Berardi, U.; Iannace, G.; Trematerra, A.; Puyana-Romero, V. The acoustics of ancient catacombs in Southern Italy. Build. Acoust. 2020. [CrossRef]

16. Ciaburro, G.; Iannace, G.; Trematerra, A.; Lombardi, I.; Abeti, M. The acoustic characteristics of the "Dives in Misericordia" Church in Rome. Build. Acoust. 2020. [CrossRef]

17. ISO 3382. Acoustics-Measurement of Room Acoustic Parameters; International Organization for Standardization: Geneva, Switzerland, 2009.

18. Vassilantonopoulos, S.L.; Mourjopoulos, J.N. A study of ancient Greek and Roman theater acoustics. Acta Acust. United Acust. 2003, 89, 123-136.

19. Shankland, R.S. Acoustics of Greek theatres. Phys. Today 1973, 26, 30-35. [CrossRef]

20. Barron, M. Auditorium Acoustics and Architectural Design; E\&FN SPON: London, UK, 1993.

21. Forsyth, M. Buildings for Music: The Architect, the Musician, the Listener from the Seventeenth Century to the Present Day; The MIT Press: Cambridge, MA, USA, 1985.

22. Álvarez-Corbacho, Á.; Bustamante, P.; Galindo, M.; Girón, S.; Zamarreño, T. Measurement and analysis of the acoustics of the Roman theatre of Segobriga (Spain). In Proceedings of the INTER-NOISE and NOISE-CON Congress and Conference Proceedings, InterNoise19, Madrid, Spain, 16-19 June 2019.

23. Álvarez-Morales, L.; Zamarreño, T.; Girón, S.; Galindo, M. A methodology for the study of the acoustic environment of Catholic cathedrals: Application to the Cathedral of Malaga. Build. Environ. 2014, 72, 102-115. [CrossRef]

24. Iannace, G.; Trematerra, A. The acoustic effects of the audience in the modern use the of ancient theatres. J. Teknol. 2018, 80, 147-155. [CrossRef]

25. Long, M. Architectural Acoustics, 2nd ed.; Academic Press: Cambridge, MA, USA, 2014.

26. Iannace, G.; Berardi, U.; De Rossi, F.; Mazza, S.; Trematerra, A.; Ciaburro, G. Acoustic enhancement of a modern church. Buildings 2019, 9, 83. [CrossRef]

27. Berardi, U.; Iannace, G.; Maffei, L. Virtual reconstruction of the historical acoustics of the Odeon of Pompeii. J. Cult. Herit. 2016, 19, 555-566. [CrossRef]

28. Trematerra, A.; Paternuostro, S.; Lombardi, I. Virtual reconstruction and sound field simulation of the Odeon of Posillipo. In Proceedings of the 16th Conference on Applied Mathematics, APLIMAT 2017, Bratislava, Slovakia, 31 January-2 February 2017.

29. Iannace, G.; Trematerra, A.; Masullo, M. The large theatre of Pompeii: Acoustic evolution. Build. Acoust. 2013, 30, 215-227. [CrossRef]

30. OmniPower Sound Source Type 4292-L Technical Datasheet. Available online: https://www.bksv.com/en/transducers/acoustic/ sound-sources (accessed on 18 May 2021).

31. ISO 3747. Determination of Sound Power Levels of Noise Sources Using Sound Pressure Comparison Method for Use in Situ; International Organization for Standardization: Geneva, Switzerland, 2011.

32. Farnetani, A.; Prodi, N.; Pompoli, R. On the acoustics of ancient Greek and Roman theaters. J. Acoust. Soc. Am. 2008, 124, 1557-1567. [CrossRef] [PubMed]

33. Bo, E.; Astolfi, A.; Pellegrino, A.; Pelegrin-Garcia, D.; Puglisi, G.E.; Shtrepi, L.; Rychtarikova, M. The modern use of ancient theatres related to acoustic and lighting requirements: Stage design guidelines for the Greek theatre of Syracuse. Energy Build. 2015, 95, 106-115. [CrossRef]

34. Rindel, J.H. Roman Theaters and the Revival of Their Acoustics in the ERATO Project. Acta Acust. 2013, 99, 21-29. [CrossRef]

35. Chourmouziadou, K.; Kang, J. Acoustic evolution of ancient Greek and Roman theatres. Appl. Acoust. 2008, 69, 514-529. [CrossRef]

36. Lokki, T.; Southern, A.; Siltanen, S.; Savioja, L. Acoustics of Epidaurus-Studies with Room Acoustics Modelling Methods. Acta Acust. 2013, 99, 40-47. [CrossRef]

37. Declercq, N.F.; Dekeyser, C.S.A. Acoustic diffraction effects at the Hellenistic amphitheater of Epidaurus: Seat rows responsible for the marvelous acoustics. J. Acoust. Soc. Am. 2007, 121, 2011-2022. [CrossRef] [PubMed]

38. Berardi, U.; Iannace, G. The acoustic of Roman theatres in Southern Italy and some reflections for their modern uses. Appl. Acoust. 2020, 170, 107530. [CrossRef]

39. Girón, S.; Álvarez-Corbacho, Á.; Zamarreño, T. Exploring the acoustics of ancient open-air theatres. Arch. Acoust. 2020, 45, 181-208. [CrossRef] 
40. Alfano, F.R.D.; Iannace, G.; Ianniello, C.; Ianniello, E. "Velaria" in ancient Roman theatres: Can they have an acoustic role? Energy Build. 2015, 95, 98-105. [CrossRef]

41. Iannace, G.; Trematerra, A. Evaluation of the acoustics of the Roman theatre in Benevento for discrete listening points. In Proceedings of the 143rd Audio Engineering Society Convention 2017, New York, NY, USA, 18-21 October 2017; Volume 2, pp. 645-653.

42. Iannace, G.; Ciaburro, G.; Trematerra, A. The acoustics of the holy family church in Salerno. Can. Acoust. 2020, $48,1$. 